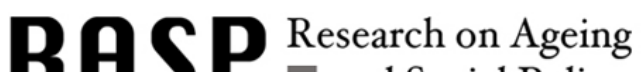
and Social Policy

Instructions for authors, subscriptions and further details:

http://rasp.hipatiapress.com

\title{
“I Think I'm Better at it Myself”: The Capability Approach and Being Independent in Later Life
}

Louise Meijering $^{1}$, Bettina van Hoven ${ }^{1}$ \& Sepideh Yousefzadeh ${ }^{1}$

1) University of Groningen. The Netherlands

Date of publication: January $30^{\text {th }}, 2019$

Edition period: January 2019- June 2019

To cite this article: Meijering, L., van Hoven, B. \& Yousefzadeh, S. (2019). "I think I'm better at it myself": the capability approach and being independent in later life. Research on Ageing and Social Policy, 7(1), 229259. doi: 10.4471/rasp.2019.3678

To link this article: http://dx.doi.org/10.447/rasp.2019.3678

PLEASE SCROLL DOWN FOR ARTICLE

The terms and conditions of use are related to the Open Journal System and to Creative Commons Attribution License (CCAL). 


\section{"I Think I'm Better at it Myself": The Capability Approach and Being Independent in Later Life}

Louise Meijering

University of Groningen

Sepideh Yousefzadeh

University of Groningen
Bettina van Hoven

University of Groningen

(Received: 3 August 2018; Accepted: 14 October 2018; Published: 30 January 2019)

\section{Abstract}

In this article, we use the capability approach to explore how individual capabilities and contextual opportunities and restrictions contribute to being independent in later life. A qualitative methodology was adopted and we conducted in-depth interviews with 32 adults aged 65 and older, who lived independently and in sheltered housing. The study was carried out in two urban neighborhoods in the North of the Netherlands. Our findings underline that different pathways to independence are shaped by individual resources and capabilities, as well as by social and physical characteristics of the living environment.

Keywords: capability approach; independence; the Netherlands; older adults; qualitative research; urban neighborhood 


\section{"Creo que lo hago mejor yo mismo": Enfoque de Capacidad e Independencia en la Edad Avanzada}

Louise Meijering

University of Groningen

Sepideh Yousefzadeh

University of Groningen
Bettina van Hoven

University of Groningen

(Recibido: 3 agosto 2018; Aceptado: 14 octubre 2018; Publicado: 30 enero 2019)

\section{Resumen}

En este artículo, usamos el enfoque de la capacidad para explorar cómo las capacidades individuales y las oportunidades y restricciones contextuales contribuyen a que las personas mayores sean independientes. Se adoptó una metodología cualitativa y realizamos entrevistas en profundidad con 32 mayores de 65 años, que vivían independientemente y en viviendas protegidas. El estudio se realizó en dos barrios urbanos del norte de los Países Bajos. Nuestros hallazgos subrayan que los diferentes caminos y formas de independencia se basan en los recursos y capacidades individuales, así como en las características sociales y físicas del entorno de vida.

Palabras clave: enfoque de capacidad; independencia; Países Bajos; personas mayores; investigación cualitativa; barrio urbano 
$\mathrm{s}$ a response to ageing societies, policies in the global northwest have begun to target societal concerns around ageing through healthy ageing policy frameworks. Often these take shape in policies that stimulate ageing-in-place which emphasize that growing old in one's own home and neighborhood is in the best interest of older adults. As Davies and James (2011) argue, ageing-in-place enables older adults to age within a familiar and predictable environment that is supportive of their social, emotional and instrumental needs. In recent years, policies that stimulate ageing-in-place have been criticized for giving priority to individual responsibilities and responses, whilst undervaluing the role that the physical, social and economic environments play in determining health outcomes for older adults, such as depressive symptoms, chronic diseases, and gait speed. It needs to be acknowledged that the ways in which age and ageing is experienced and valued differs between different contexts and as a result of interactions of people with institutions, discourses and social structures (van Hoven et al., 2012).

The discourse on ageing has been marked by dominant paradigms of ageism, focusing on the decline, disease and (economic and social) burden associated with ageing on the one hand; and of healthism, focusing on healthy, active and successful ageing on the other (Stephens, 2016; Stephens \& Breheny 2019). As a result of these dominant normative discourses, little room remains for narratives that foreground ageing successfully with disability or illness, or ageing not as loss but as affording new freedoms and new relationships. These opportunities may arise as older adults manage to reconstruct their identities based on the structural conditions in which they find themselves (e.g. retirement, welfare institutions). Indeed, research has shown that older adults can be resilient and develop coping strategies to manage their ageing process (MacLeod et al., 2016; Phillips et al., 2016). Therefore, research needs to be done on how older adults can live a meaningful life in the context of the impairments they experience.

As we argued above, the connection between individual and contextual factors shape experiences of later life. The interplay between individual agency and the context in which individuals function is emphasized in Sen's capability approach (1999). The capability approach is a theoretical 
framework that stresses both the relevance of agency and choice in individuals' lives, as well as the contextual factors that can constrain individual freedom of choice. The capability approach goes beyond ageism or denial of physical limitations by focusing on what older adults are actually able to be and to do, hence foregrounding independence. In addition, it helps to identify diversity among people, for instance based on their socioeconomic background as well as the cluster of capabilities that older adults themselves value.

The aim of this article is to use the capability approach to explore how individual capabilities and contextual opportunities and restrictions contribute to being independent in later life. In so doing, we draw on findings from a qualitative research project on ageing and wellbeing in the Northern Netherlands. The key contribution of this article is its identification of specific capabilities that lead to achieve independence as a functioning in later life. It is one of the few studies to identify specific capabilities for older adults beyond the core capabilities that Nussbaum (2003) suggested as relevant for all individuals: life, bodily health, bodily integrity, senses, imagination, and thought, emotions, practical reason, affiliation, other species, play, and control over one's environment (Nussbaum, 2011).

\section{The Capability Approach}

Extending work by Amartya Sen and Martha Nussbaum, Robeyns (2005: 94) explained the capability approach as focusing on "what people are effectively able to do and be; that is, on their capabilities". These capabilities are made concrete in the 'beings and doings', or functionings, of people, and together these are what makes an individual life worth living. Capabilities constitute the freedom, or opportunity set, that is available to an individual, given the resources they have (Sen, 1999). Functionings are the results of choices made by individuals in the context of their structural constraints, and constitute the things that they have achieved.

People's capabilities differ, firstly because people do not have equal access to resources, such as money or education. Secondly, because "the degree in which a person can transform a resource into a functioning", or 
so-called conversion factors, differ between people (Robeyns, 2016a: 6). There are three types of conversion factors: personal conversion factors, internal to a person, encompass for instance physical condition, intelligence and metabolism. Social conversion factors stem from the society in which a person is living, and include social norms, public policies and power relations. Environmental conversion factors come from a person's physical or built environment, including, for instance, climate and pollution, as well as (rail)roads and buildings. For example, older adults may be interested in using a mobility scooter, because it can enable them to be mobile. How much a mobility scooter contributes to being mobile, is related to a person's physical condition and ability to operate the mobility scooter (personal conversion factor), whether it is socially acceptable to use a mobility scooter (social conversion factor), and the availability of roads suitable for the use of mobility scooters (environmental conversion factor).

In studying how people's capabilities, choices and achievements come about, the capability approach emphasizes the impact of both individual agency, and the socio-economic context. According to the capability approach, individuals themselves determine what a good life constitutes for them, and how they want to realize this, within the boundaries of their own capabilities (Sen, 1993). At the same time, it emphasizes that people's individual values and choices are shaped by the particular socio-economic context in which they live (Robeyns, 2005). Thus, according to the capability approach, people make choices that are embedded in their context-specific values and aspirations, with the overarching aim of optimizing their individual well-being within that context (King, 2007). Sen (1999) argued that to achieve well-being, the ability to be independent is the overarching capability. Independence can be operationalized both as a capability and a functioning, shaped by capabilities. As a capability, independence tells us whether a person is able to be independent or not. In this article, however, we examine it as a functioning, to evaluate the extent to which a person is being independent. In the following section, we discuss how the capability approach can be used to study the functioning of being independent in later life. 


\section{The Capability Approach and Independence in Later Life}

It has been argued that in later life, the capabilities available to an individual are likely subject to decline, because of (gradual and varying) processes of physical and cognitive decline (Grewal et al., 2006; Volkert \& Schneider, 2012). Gilroy (2005), however, found that older adults who moved into an institutional setting, may be wrongfully judged to have lost significant capabilities, because their move might signal decline to others. In later life, functionings may be lost as the capabilities to choose from, or opportunity set, declines with ageing. Capabilities may decline in later life due to limitations in resources or because of certain individual, societal and environmental factors (conversion factors) or because of structural constraints (welfare system). In addition, the capabilities to 'choose from' in later life are further opened up or constrained for older adults as a result of choices and achievements earlier in life. This underlines the importance of the biographical dimension when studying opportunities and choices in later life (Lloyd-Sherlock, 2002).

The capability approach is particularly relevant when studying ageing populations, because of its focus on what older adults can, rather than cannot achieve. Equally important is the observation that the capability to be independent is the essential, overarching capability in later life, and being independent the overarching functioning (Verkerk et al., 2001). Several authors further specified the capabilities that are important in later life, beyond the overarching capability of independence (see Gilroy, 2006; Grewal et al., 2006; Kimberley et al., 2012; van Ootegem \& Spillemaeckers 2010; Ryan et al., 2015; Yeung \& Breheny, 2016). The capabilities that resulted from their studies include: 1) being able to be in good physical and mental health; 2) being able to be mobile, or to get out and about, including psychological, social and exercise benefits; 3) being able to have social relations and support of family and friends; 4) being educated and able to work; 5) being able to enjoy leisure; 6) being able to engage in political life, 7) being able to live in neighborhood where one feels safe; and 8) being able to have a comfortable and secure home. Overall, these capabilities are similar to the core capabilities that Nussbaum (2003) introduced for all individuals based on their human rights and dignity. 
Some previous work (Ryan et al., 2015; Yeung \& Breheny, 2016) looked beyond specific capabilities into how individual and contextual factors contribute to being independent, and living a life worth living. Our study also requires such a comprehensive approach, as it aims to unravel how being independent in later life is made possible and constrained by both individual and contextual factors. The contribution of our study lies in its identification of specific capabilities that lead to achieve being independent, beyond the core capabilities for all individuals as suggested by Nussbaum (2003).

\section{Research Context}

This article draws on a larger project aimed to increase insight into older adults' everyday experiences of ageing, home and neighborhood, in relation to their well-being. The study was carried out in the city of Groningen in the North of the Netherlands, which is characterized by a compact built environment. As elsewhere in the Netherlands, policies are aiming to keep older adults living independently for as long as possible. The municipality of Groningen tries to develop neighborhoods with services and facilities such as supermarket, drug store, and GP within a 500 meter radius from age-appropriate housing. This should result in neighborhoods where older adults can comfortably age in place (van Schie et al., 2004). Additionally, mobility aids are provided by health insurance companies or municipalities. These include, for example, walkers and mobility scooters. Opportunities for social interaction are also created. For example, less expensive breakfasts or coffee are available during certain hours of the day in some retail stores with restaurants, and community centers offer games, company, as well as sometimes help with arrangements around housing, healthcare and welfare, typically supported by volunteers.

We conducted the study with older adults in two suburban neighborhoods. The neighborhoods were built in the 1960s and 1970s. Both neighborhoods are dominated by residential buildings, characterized by a mix of terraced houses and apartments. The houses are a mix of (subsidized) rent and owner occupation. In addition, both neighborhoods have sheltered housing and other institutional living facilities for older 
adults, such as residential care homes and nursing homes. They are also similar in terms of distances and access to services. In each neighborhood, there is a shopping center, with supermarkets, a hairdresser, drug store, restaurants and other everyday services. The neighborhoods also have other facilities, such as a GP, churches, and schools. The populations of both neighborhoods have significant shares of students and ethnic minorities, in comparison with other urban neighborhoods in the Northern Netherlands (KING, 2017).

Neighborhood 1 has been subject to extensive urban renewal at the start of the millennium, as a result of urban decay and deteriorated housing. Neighborhood 2 has not been renewed yet and both the housing stock and the neighborhood have been subject to degradation, for instance in terms of noise nuisance, drug abuse, dumped garbage, poorly maintained gardens (Leefbaarometer, 2014). Urban renewal in this neighborhood started in 2017, after data for the study had been collected.

\section{Methodology}

\section{Research Design}

Data were collected by in-depth interviews, during which topics such as social contacts, daily activities, health, mobility, home, institution and environment, were discussed. Potential participants were informed about the study by a letter, which was delivered via their mailbox, rather than approaching people in public space. The day after the letter was distributed, the interviewers (trained graduate students) went to ask potential participants in person whether they had read and understood the letter, explained the purpose of the study again, and asked whether they would like to participate in the research. The interviewers confirmed the participants' understanding of the study and all participants gave written informed consent. A self-selected sample of 32 older adults participated in an in-depth interview. The participants' background characteristics are recorded in Table 1 . The names used in the table are pseudonyms. In each of the neighborhoods, we interviewed both participants who lived independently, and who lived in sheltered housing. The participants who 
lived independently either inhabited an apartment or a terraced house, built in the 1960s. Sheltered housing is a form of 'ageing in place', where individual apartments are adapted to meet the current and future care needs of older adults. The participants' sheltered housing apartments have, for example, widened doorposts and hallways to accommodate walkers, mobility scooters and wheelchairs; no doorsteps; elevated toilet seats, and brackets on the wall in the bathroom.

Table 1

Participant Characteristics.

\begin{tabular}{|c|c|c|c|c|c|}
\hline Pseudonym & Age & Gender & $\begin{array}{c}\text { Years in } \\
\text { neighborhood }\end{array}$ & $\begin{array}{c}\text { Type of } \\
\text { residence }\end{array}$ & $\begin{array}{c}\text { Neighbor } \\
\text { - hood }\end{array}$ \\
\hline Mr. Baker & $91-95$ & M & unknown & $\begin{array}{l}\text { Sheltered } \\
\text { housing }\end{array}$ & 1 \\
\hline Mrs. Caspers & $76-80$ & $\mathrm{~F}$ & $0-5$ & $\begin{array}{l}\text { Sheltered } \\
\text { housing }\end{array}$ & 1 \\
\hline Mrs. Hart & $76-80$ & $\mathrm{~F}$ & $0-5$ & $\begin{array}{l}\text { Sheltered } \\
\text { housing }\end{array}$ & 1 \\
\hline Mrs. Jensen & $56-60$ & $\mathrm{~F}$ & $0-5$ & $\begin{array}{l}\text { Sheltered } \\
\text { housing }\end{array}$ & 1 \\
\hline Mrs. Lutz & $76-80$ & $\mathrm{~F}$ & $0-5$ & $\begin{array}{l}\text { Sheltered } \\
\text { housing }\end{array}$ & 1 \\
\hline Mrs. Page & $71-75$ & $\mathrm{~F}$ & $0-5$ & $\begin{array}{l}\text { Sheltered } \\
\text { housing }\end{array}$ & 1 \\
\hline Mrs. Veitch & $81-85$ & $\mathrm{~F}$ & $0-5$ & $\begin{array}{l}\text { Sheltered } \\
\text { housing }\end{array}$ & 1 \\
\hline Mrs. Vink & $81-85$ & $\mathrm{~F}$ & $41-50$ & Apartment & 1 \\
\hline Mrs. van der Zee & $86-90$ & $\mathrm{~F}$ & $21-30$ & $\begin{array}{l}\text { Sheltered } \\
\text { housing }\end{array}$ & 1 \\
\hline Mrs. van der Pol & $81-85$ & $\mathrm{~F}$ & $21-30$ & Apartment & 1 \\
\hline $\begin{array}{l}\text { Mrs. van Dijk Joint } \\
\text { interview with Mrs. } \\
\text { Martens }\end{array}$ & $66-70$ & $\mathrm{~F}$ & $6-10$ & Apartment & 1 \\
\hline $\begin{array}{l}\text { Martens } \\
\text { Mrs. Martens }\end{array}$ & $71-75$ & $\mathrm{~F}$ & $11-20$ & Apartment & 1 \\
\hline Mrs. De Jager & $76-80$ & $\mathrm{~F}$ & $31-40$ & Apartment & 1 \\
\hline Mrs. Bos & $86-90$ & $\mathrm{~F}$ & $41-50$ & Apartment & 1 \\
\hline Mrs. Berends & $76-80$ & $\mathrm{~F}$ & $41-50$ & Row house & 1 \\
\hline $\begin{array}{l}\text { Mr. de Waard Joint } \\
\text { interview with Mr. } \\
\text { Kremer }\end{array}$ & $71-75$ & M & $11-20$ & Row house & 1 \\
\hline Mr. Kremer & $66-70$ & M & $21-30$ & Row house & 1 \\
\hline Mr. Torenstra & $61-65$ & M & $21-30$ & $\begin{array}{l}\text { Sheltered } \\
\text { housing }\end{array}$ & 1 \\
\hline
\end{tabular}


Table 1

Participant Characteristics (continued).

\begin{tabular}{|c|c|c|c|c|c|}
\hline Mr. Kamphuis & $81-85$ & M & $21-30$ & Apartment & 1 \\
\hline $\begin{array}{l}\text { Mrs. Pieters Joint } \\
\text { interviews with Mr. }\end{array}$ & $71-75$ & $\mathrm{~F}$ & $41-50$ & Row house & 1 \\
\hline $\begin{array}{l}\text { Pieters } \\
\text { Mr. Pieters }\end{array}$ & $76-80$ & M & $41-50$ & Row house & 1 \\
\hline Mr. Kamminga & $76-80$ & M & $41-50$ & Row house & 2 \\
\hline Mrs. Wilkens & $76-60$ & $\mathrm{~F}$ & $6-10$ & Apartment & 2 \\
\hline Mr. Roelofs & unknown & M & $41-50$ & Apartment & 2 \\
\hline Mrs. Eck & $86-90$ & $\mathrm{~F}$ & $41-50$ & Apartment & 2 \\
\hline Mr. Gerritsen & $81-85$ & M & $41-50$ & Row house & 2 \\
\hline Mrs. Martens & $81-85$ & $\mathrm{~F}$ & $41-50$ & Apartment & 2 \\
\hline Mrs. Mulder & $76-80$ & F & $0-5$ & $\begin{array}{l}\text { Sheltered } \\
\text { housing }\end{array}$ & 2 \\
\hline Mr. Petersen & unknown & M & $31-40$ & Row house & 2 \\
\hline Mr. Aalders & $76-80$ & M & $41-50$ & Apartment & 2 \\
\hline Mrs. Geldof & unknown & $\mathrm{F}$ & $6-10$ & $\begin{array}{l}\text { Sheltered } \\
\text { housing }\end{array}$ & 2 \\
\hline Mr. Jorritsma & unknown & M & $41-50$ & $\begin{array}{l}\text { Sheltered } \\
\text { housing }\end{array}$ & 2 \\
\hline
\end{tabular}

Through including older adults who live independently, as well as sheltered housing residents, we are able to study participants in their third age and (nearing) fourth age (see Gilleard \& Higgs, 2010). The third age concerns retired older adults who are living an active life, who have little age-related impairments. The fourth age concerns older adults with increasing age-related impairments and care needs. Through using the capability approach as the theoretical lens, we were able to foreground the capabilities of both participants in their third and fourth age, instead of focusing on impairments.

The information disclosed by the participants as well as their identities were treated confidentially. Research assistants transcribed the data in QSR NVivo 8.0. Thematic data-analysis was done by both authors (see also Joffe $\&$ Yardley, 2003). In the process of data-analysis, an informed grounded theory approach was adopted (Thornberg, 2012). We coded the data independently, and discussed our findings, in an iterative process. In this process, the capability approach and independence as a key-functioning emerged as a relevant theory to guide the analysis. We attempted to deconstruct the functioning of being independent in later life into the resources, capabilities, conversion factors that shape it. 


\section{Findings}

Through our analysis, we identified three capabilities that contribute to the achieved functioning of being independent in later life, namely the capability to: 1) to be comfortable at home and in the neighborhood; 2) enjoy a fulfilling social life; 3) be mobile. In discussing each of these capabilities in turn, we show how they are shaped by both contextual and individual factors, and how they in turn shape the functioning of being independent.

\section{The Capability to Be Comfortable at Home and in the Neighborhood}

In talking about having a comfortable home, most participants discussed characteristics of both their house and neighborhood that made them feel (not) at home. Most participants who lived independently had typically decided that this was the place where they would like to age. This decision was often related to a deep-felt familiarity with and attachment to the neighborhood, its inhabitants and services. In neighborhood 2 in particular, there was a large group of older adults who had lived there for a long time, sometimes since its construction in the 1960s:

Interviewer: You want to stay in [neighborhood 2]?

Mr. Aalders: Yes. Although [the neighborhood] has decayed. But this is our living environment. If we would have to go to, say [mentions another neighborhood in Groningen], I'd hate it. [...] It is like this, your life. well I know a lot of people here, not by name, but just in saying "hi", and "hi". [...] And when I go downstairs, I can choose whichever supermarket, or we walk a couple of blocks to yet another one. (Mr. Aalders, age group 76-80, apartment, neighborhood 2)

Similar to Mr. Aalders, many participants in row houses and apartments articulated that they made the decision to stay because of their familiarity with the neighborhood and its residents. As part of the familiarity with the neighborhood, our participants typically enjoyed the daily contacts with their neighbors, shopkeepers, and other familiar faces. For the residents 
who lived in sheltered housing, different affective processes seemed to play a role in feeling at home. Many participants motivated their move into this particular sheltered housing facility because of its vicinity to significant others, for instance children.

When further zooming in to the home, we found that our participants tried to engage in everyday activities in the home that were meaningful to them. For instance, some participants chose to engage in housekeeping, because that enhanced their feeling of self-worth and enjoyment in life:

I do not have a housekeeper [...] I would not like to give [the household tasks] away and I do not hear good things about it either. I think I'm better at it myself. [...] And I do the laundry and ironing and cooking [for my youngest son] so that's a whole lot. (Mrs. Page, age group 71-75, sheltered housing, neighborhood 1)

For Mrs. Page, engaging in household tasks enabled her to have a comfortable home. Others, in contrast, disliked doing household tasks, and sought support for household tasks they did not enjoy, such as cleaning, ironing and doing the laundry:

I don't do any housekeeping, I get help once a week and she does it (Mrs. Caspers, age group 76-80, sheltered housing, neighborhood 1)

Mrs. Caspers evaded doing activities she disliked, such as cleaning, ironing and doing the laundry. Rather, she used money as a resource to pay her housekeeper. Employing a housekeeper, enabled her to spend time and energy to spend on activities that she valued, such as reading and spending time with her friends and children, which resulted in her being comfortable at home: "I only wanted to move here if I could have a guest room [for my friends and children to stay over.]". This illustrates two different pathways towards having a comfortable home. Through using the capability approach, we were able to identify these individual differences, not only in resources and conversion factors, but also in agency.

For many participants, however, being comfortable in their home was not straightforward. Our analysis brought the relevance of socio-economic differences to light, as in some cases, participants lacked income as a 
resource, to arrange practical support and care, which would contribute to being comfortable at home. Mrs. Jensen, for instance, had moved into the Feldspar after experiencing a stroke at a relatively young age. She suffered from hemiplegia and fatigue and would have liked to be relieved from the burden of cooking, to be more comfortable at home. However, she explained that the food prepared in the institution's kitchen was too expensive:

I have to live of social benefits. [...] You can't just think, I just buy stuff, because you'll understand, with 300 euros [a month], you can't afford to eat here every day for 7 euro 50, then you're left with nothing, you can't smoke, I take a couple of drinks every day, well you wouldn't be able to afford those, then you could hardly afford to buy a biscuit, well I wouldn't feel like that. (Mrs. Jensen, age group 56-60, sheltered housing, neighborhood 1)

Mrs. Jensen perceived that having to cook for herself, left her with less time and energy to engage in other valued activities, such as knitting and painting. However, when looking at her story from a capability perspective, we see that she did exert agency, in prioritizing her capabilities to drink and smoke - which she converted into achievements - over her capability to eat at the restaurant. This shows that, even though she framed it as a forced decision, Mrs. Jensen did have some negotiating space to prioritize one functioning over the other.

In other cases participants were entitled to get support with activities of daily living, and had the resources for it. Mrs. Lutz, for instance, could get assistance with showering thrice a week, because of her limited physical capabilities. However, she made the decision to get help just once a week:

I like to receive help when taking a shower [because I am at risk of falling], but I can do the rest myself. If I get help showering one day, I can wash myself during the rest of the week. I put a towel on my [walker], I place it in front of the washbasin, and I know how to wash myself. (Mrs. Lutz, age group 76-80, sheltered housing, neighborhood 1) 
Mrs. Lutz chose to receive less practical support than she was entitled to, because she wanted to be as independent as possible. This choice implied that she needed to spend quite a lot of time and energy on personal care, drawing on her capability to maintain her health. As a result, she sometimes had no energy left to engage in other activities she valued besides being able to maintain her health, such as meeting a friend or doing needlework. Still, for her, washing herself contributed more to having a comfortable home, than these other activities would have and she made choices within her capability sets.

\section{Enjoying a Fulfilling Social Life}

Many participants emphasized how the capability to maintain social relations with family members, children in particular, and friends, was important for them. Having children, siblings and friends can be considered resources, while how well one gets on with one's family and friends is a personal conversion factor. Mrs. Caspers, for instance, described how she appreciates the close relationship she has with her three children. She told us that she moved back to [town] because her youngest son had also moved there:

[I]f I would not have had a son here, I would not have gone back [to specific town]. He goes shopping with me every week, $[\ldots]$ and from time to time they invite me over for dinner. [...] I get on very well with my children, I have very nice children. (Mrs. Caspers, age group 76-80, sheltered housing, neighborhood 1)

Mrs Caspers' move contributed to her being part of a social network, in which her children played a key role. Similarly, our other participants assigned much importance to the capability to maintain social relations, especially, with children, siblings and friends.

In our study, the participants underlined the significance of both giving and receiving social support in the capability to have a fulfilling social life. Mr. Aalders explained how recurring reciprocal activities contributed to his social ties with his son and grandsons: 
Grandpa [refers to himself], he has a son, and two grandsons, and they all have a season ticket for [the local soccer team]. Grandpa pays for it [laughter]. And every home game, they come here around eleven, have a cup of coffee, eat a sandwich, go to see the soccer match, come back and then a hot meal is waiting for us [prepared by Mr. Aalders' wife]. And when that's done, they go back home. (Mr. Aalders, age group 76-80, apartment, neighborhood 2)

Mr. Aalders' story is in part about reciprocity - he pays the tickets, his wife cooks the food, his sons and grandsons provide the company and care, if needed. But perhaps more significantly, it is also about how social routines contribute to a sense of feeling connected with other people.

Many participants told us how their social network of close ties in general was subject to decline, with friends and relatives moving into institutional settings elsewhere, or passing away. However, most participants decided not to invest in building up new relations, as they felt that was a big investment to make, and they would be afraid of losing such new friendships again. For instance, Mrs. van Dijk told us:

I used to have a friend, with whom I had a really close friendship. But well, she passed away too. And that has an impact, and you become careful. You don't dare to get too closely involved with people anymore. (Mrs. van Dijk, age group 66-70, apartment, neighborhood 1)

Mrs. Van Dijk's story illustrates that the loss of her close friend had such an impact on her, that she decided she did not want to go through that again. As a result, she made the choice not to invest in new close friendships. Similar choices were articulated by our other participants. With close friendships declining, most participants did enjoy some superficial contacts within their residences and neighborhoods. As mentioned in the previous section, for some long-term residents, this 'social familiarity' was a motivation to stay in the neighborhood. 


\section{The Capability to be Mobile}

Being mobile, especially in the neighborhood, contributed to being independent. In this context, it should be noted that most participants experienced that their capability to be mobile was subject to decline and that this rendered them more vulnerable. First, we look at this physical vulnerability as a personal conversion factor that impacts mobility. Second, we discuss the participants' perceived vulnerability in relation to the changing physical and social environment - environmental and social conversion factors.

In general, participants who had physical impairments often considered carefully when and how they would go out. For example, Mrs. Mulder, who suffered from rheumatism and restricted eyesight recalled:

Well, since I have the walker, I dare to go out more, I think. [...] When the weather is nice, I would go around the block. Not too far. Because there's a bench somewhere there. [...] On the waterfront. And when I would walk to the shopping center, well there's a bench in front of [an apartment block] and there is a large stone bench in the shopping center itself. I know that by now. (Mrs. Mulder, age group 76-80, sheltered housing, neighborhood 2)

Although Mrs. Mulder is impaired in her outdoor movement in the neighborhood, resources such as a walker, and aspects of the environment including benches and good weather facilitate her moving about (environmental conversion factors).

While increased vulnerability itself already impacted on the participants' mobility, its impact reaches still further when connecting it to the neighborhood contexts, in terms of crime and traffic safety. In neighborhood 2 in particular, participants observed that the neighborhood had 'deteriorated' in recent years, which they often related to the increasing share of students, ethnic minorities and drug dealers in the neighborhood. In both neighborhoods, perceived crime levels contributed to the participants sometimes feeling unsafe on the streets. Mrs. Lutz told us: 
Well and then I stand there in that hall, before entering the store, and then I come in with my walker [...] and it's 200 percent visible that I am disabled. I am not ashamed of that, but I am scared that they will give me a quick kick when I am outside, and take my purse. [...] it's always old people they choose to rob. (Mrs. Lutz, age group 76-80, sheltered housing, neighborhood 1)

In Mrs. Lutz' experience, crimes such as robberies would occur in her neighborhood. Using a walker enabled her to be mobile, but at the same time it marked her as vulnerable and an easy target for criminals, which made her more reluctant to go out.

Traffic safety was another issue that impacted being mobile in neighborhood 2. Several participants told us about the irresponsible traffic behavior they observed in and around the neighborhood shopping center:

Mrs. Martens: [Looking and pointing outside] Bicycles too, two bicycles, they almost crashed. Look, and then there's coming one from that way, from that square. [...] It should not be allowed. That they are going across the square, with motorcycles and all. Your life is at risk, when you're walking there. Honestly. I sometimes think, oh my goodness, I'm not that quick anymore. (Mrs. Martens, age group 71-75, apartment, neighborhood 1)

Although the center is officially a pedestrian area, many cyclists and moped drivers ride through it, which leads to dangerous situations. As a result, some participants, especially those with walking disabilities, had become afraid to go to the shopping center and rather stayed at home.

In dealing with the changing neighborhood contexts and their own vulnerabilities, the participants developed different coping strategies. As was outlined above, some participants chose to stay at home, perhaps more often than they would have like to. While many participants reported not going out at night, some participants did find ways to be mobile. Mr. Gerritsen, for instance, told us that he uses his car when he goes out in the evenings:

Mr. Gerritsen: I [go into town] by car now.

Interviewer: Because it's at night? 
Mr. Gerritsen: Yes, I don't do that by bike anymore. [...] It's lack of safety. Pure lack of safety. I don't go there by bike. During the day, I do cycle into town, I don't care, but I don't cycle to places at night anymore. (Mr. Gerritsen, age group 81-85, row house, neighborhood 2)

Mr. Gerritsen had chosen to go out at night only by car, because he felt unsafe when cycling and walking. This feeling of unsafety was shared by many other participants. However, many other participants did not have a car. Hence, the role of individual capabilities and financial resources are important in this story, and it illustrates the inequalities between different participants. Unlike Mr. Gerritsen, many other participants could either not drive a car anymore, or did not have the resources to buy a car.

\section{Discussion}

In this article, we uncovered how older adults living independently and in sheltered housing, in two urban neighborhoods in the Northern Netherlands, achieve being independent. This study enabled us to contribute to the discourse of the capability approach beyond the abstract in different ways. First, we provide a nuanced view on how older adults themselves define capabilities that are crucial to their independence. The second contribution is in providing details on how those capabilities are prioritized differently among individuals. From a policy perspective, this is an important finding to advocate treating individual older adults as holders of capabilities (Robeyns, 2016b). Third, the article provides greater understanding individual capabilities vis-à-vis collective performances. Fourth, we focused on evaluating independence as a particular achievement, rather than on wellbeing as a general functioning, which is often done in studies that use the capability approach in later life (e.g. Antczak \& Zaidi, 2018; van Ootegem \& Spillemaeckers, 2010). Finally, we were able to go deeper in our analysis, to understand what older adults value in their life (i.e. independence) and how do they define the pathways to achieve it (in terms of capabilities, as well as resources, conversion factors and agency). 
248 Meijering et al. - "I Think I'm Better at it Myself"

Table 2

Findings in terms of the concepts from the capability approach.

\begin{tabular}{|c|c|c|c|}
\hline $\begin{array}{l}\text { Endowments or } \\
\text { resources }\end{array}$ & Conversion factors & Capabilities & Functionings \\
\hline $\begin{array}{l}\text { Access to market, } \\
\text { shopping centers } \\
\text { Food availability } \\
\text { Money, income } \\
\text { Food price } \\
\text { Availability of social } \\
\text { safety-nets (welfare } \\
\text { system) } \\
\text { Infrastructure } \\
\text { Supportive family, } \\
\text { friends and peers } \\
\text { Friends, relatives } \\
\text { Community center } \\
\text { Own house }\end{array}$ & $\begin{array}{l}\text { Gender } \\
\text { Physical health } \\
\text { Traffic and road } \\
\text { safety } \\
\text { Socioeconomic } \\
\text { status } \\
\text { Cultural traditions } \\
\text { Safety } \\
\text { Fear (of loss) } \\
\text { Weather conditions } \\
\text { Physical distance } \\
\text { (from family } \\
\text { members) } \\
\text { Lack of energy to } \\
\text { socialize } \\
\text { Troubled family } \\
\text { relations } \\
\text { Shame }\end{array}$ & $\begin{array}{l}\text { Being able to stay in a } \\
\text { familiar neighborhood } \\
\text { Being able to live in a safe } \\
\text { and stress-free environment } \\
\text { Being able to have a } \\
\text { comfortable and tidy home } \\
\text { Being able do own laundry } \\
\text { Being able to do house } \\
\text { keeping } \\
\text { Being able to read books, } \\
\text { paint, knit } \\
\text { Being able to move about } \\
\text { Being able to interact with } \\
\text { significant others } \\
\text { Being able to socialize } \\
\text { Being able to belong to a } \\
\text { social network } \\
\text { Being able to make new } \\
\text { friends } \\
\text { Being able to maintain } \\
\text { contact with people one has } \\
\text { known for a long time } \\
\text { Being able to rest and enjoy } \\
\text { different forms of leisure } \\
\text { Being able to prepare food } \\
\text { Being able to smoke } \\
\text { Being able to drink } \\
\text { Being able to be physically } \\
\text { active } \\
\text { Being able to shower }\end{array}$ & $\begin{array}{l}\text { Being independent in } \\
\text { different aspects such } \\
\text { as: } \\
\text { Being mobile } \\
\text { Preparing one's food } \\
\text { Interacting with } \\
\text { significant others and } \\
\text { family members } \\
\text { Socializing with peers } \\
\text { and neighbors } \\
\text { Engaging in favorite } \\
\text { leisure activities } \\
\text { Showering } \\
\text { Doing one's household } \\
\text { chores }\end{array}$ \\
\hline
\end{tabular}

Table 2 categorizes our findings that were discussed in the Findings section under resources, conversion factors, capabilities and functionings. Three specific capabilities that older adults find important in achieving independence are: being comfortable at home and in the neighborhood, enjoying fulfilling social relations, and being mobile. In the capability to have a comfortable home, the decision to age in the chosen neighborhood 
played a key-role. Our participants emphasized the importance of familiarity with their everyday living environment both in terms of inhabitants and services. Furthermore, for some participants, it was important to live close to significant others, such as children. This connects to our finding that the capability to have fulfilling social relations contributes to being independent. The importance of social relations in later life, with family and friends, and with neighbors and other more superficial contact in the neighborhood, has also been emphasized in other research (Douma et al., 2017; Gilroy, 2008; Paulos \& Fragoso, 2017). Our study underlined the importance of reciprocity in managing social connectedness and supports Breheny \& Stephens' (2009) conclusions that independence and social connectedness are linked through reciprocity.

We found that the capability to be mobile also contributes to being independent (Table 2). Being mobile is connected to physical impairments as well as perceived safety of the neighborhood. Criminality and dangerous traffic situations impacted the capability to be mobile of our participants. The latter may be specific to our study setting. In the Netherlands, the idea of shared space is often applied in residential neighborhoods, which means that different traffic users move in the same space. Thus, there are no separate lanes for different traffic users (Hamilton-Baillie, 2008). Our study shows that such a concept may be not ideal for some older traffic users and potentially contributes to their feelings of unsafety. To frame it differently, the lack of traffic safety could be connected to limited walkability in a neighborhood. Previous research has shown that walkability of a neighborhood can contribute to social interactions (Rogers et al., 2011; van den Berg et al., 2017), which pinpoints the potential connection between the capabilities of being mobile and enjoying a fulfilling social life. It may be worthwhile to explore this connection in future research. Furthermore, in our study, feelings of unsafety were tied to the participants' experiences of their own bodies as vulnerable. This links with research findings by Lager et al. (2015: 87) where older adults reported they stayed indoors after dark, through which "ageist stereotypes of older adults' body capital" were revealed.

Overall, our findings confirmed that being independent is an overarching functioning in later life (Sen, 1999). Conceptually, 
independence consists of autonomy and self-reliance (Schwanen et al., 2012). Autonomy, or being able to make one's own decisions, was key to being independent. Self-reliance, or being able to carry out activities oneself, also played an important role. Balancing the need to be independent, in the context of declining capabilities, proved to be a challenge for our participants. This confirms the literature on independence, especially in the context of sheltered housing, residential care and other assisted living facilities with residents often in their fourth age, where lack of autonomy and self-reliance of residents is often discussed (Custers et al., 2012; Hammarström \& Torres, 2010; Shura et al., 2010).

However, our findings also uncovered the agency of older adults, both in their third and fourth age. Our participants exhibited agency in the choices they make as to which activities to engage in, which people to meet, and where to go. This sheds light on how older adults navigate between the set of capabilities they have, and how they choose different combinations in order to achieve what they value. Our findings align well with literature on resilience and coping in later life (Dunér \& Nordström, 2005; MacLeod et al., 2016; Phillips et al., 2016). In connection to these studies, we can conclude that our study underlined the mental, social and physical resilience of older adults, as well as different coping strategies to manage the challenges of everyday life. At the same time, our study demonstrates that ageing independently, in both third and fourth age, can be restricted by a lack of resources and capabilities, and is thus not equally possible for all older adults. In this respect, our findings confirm those from another Dutch study by Van der Meer et al. (2008), which showed that older adults who were more vulnerable in terms of experienced physical impairments, were less satisfied with their neighborhood, and felt less safe.

A specific contribution of our study is that we unpacked how older adults decide to stay in a neighborhood, in spite of the negative developments they observed and experienced, especially in neighborhood 2 . We showed that older adults who had become 'experts' of their neighborhood through engaging with it over time, would feel comfortable there and decide to stay, in spite of ongoing and further deterioration. Previous research by Smith (2009) on older adults ageing in place in Manchester and Vancouver confirmed this. This finding illustrates the 
advantage of using the capability approach in studies on independence in later life, as it enables a shift in focus towards the capabilities that support older adults to achieve independence as their valued functioning, rather than on how 'successfully' they age.

It is important to note that this study was performed in a context with relatively strong welfare system for older adults, and that our findings are situated in these welfare and care policies. While some concerns were raised about negotiating budgets under different expenditures (e.g. drinking with friends versus smoking), having a retirement income at all was never an issue. Another example is about age friendly urban policies where often benches are available in short distances and make it easier for older adults or persons with physical impairments to rest when they need.

A key finding that is important from a public policy perspective is that expanding opportunities (capabilities) of older adults strengthens their agency and enable them to make choices according to what they value most. Thus, policies should focus on expanding those opportunities. For instance, in the study context, older adults typically have sets of opportunities to choose from (e.g. support with taking a shower, or housekeeping) and they choose the one that makes them happier. Thus, in order to design policies that expand capabilities of older adults and their quality of life, we need to design studies that enhance our knowledge about valued capabilities of older adults in their own context. Similarly, we need to identify the physical, social and environmental conversion factors as well as structural constraints that might limit their capabilities and agency and design policies to address these constraints. For instance, if the mobility of older adults is constrained by other road or sidewalk users, traffic sings might be used to inform other road users about potentially more vulnerable older adults.

There are some limitations to our study. First, as a result of conducting in-depth interviews, our data on the concrete interactions of older adults with everyday places are limited. Second, although our in-depth interviews produced very rich data, we did not achieve data-saturation for different groups of older adults. For instance, the gendered nature of resources, capabilities, conversion factors and functionings in later life would be worth further exploration (see Gopinath, 2018). What is innovative in our 
approach is that we studied resources, capabilities, conversion factors and functionings in relation to each other, while most other studies focus on capabilities or functionings alone (Gilroy, 2006; van Ootegem \& Spillemaeckers, 2010). Therefore, we were able to uncover how being independent can work in different ways, depending on the resources older adults have; how these resources are shaped by conversion factors; that this may lead to different capability sets; and that older adults choose which capabilities to convert into achievements or functionings.

\section{Conclusions}

We found that independence in later life is shaped by three specific capabilities: being comfortable at home and in the neighborhood, enjoying a fulfilling social life, and being mobile. In turn, these capabilities are affected by resources and conversion factors, that work at both the individual and contextual level. The interplay between individual and context gains further meaning as the key-capabilities in later life that we identified largely mirror dimensions of age-friendly environments (WHO 2007; 2015): outdoor environment, transport and mobility, housing, social participation and social inclusion. The idea of age-friendly environments in general, and dementia-friendly environments as a specific example, centers around the thought that the living environment can enable people in their third and fourth age to age how they want, and while exercising control over their lives (Buffel et al., 2014; Kendig \& Phillipson, 2014; Mitchell \& Burton, 2006). We would like to recommend policies that provide older adults with more choices and opportunities to achieve independence, so that they could choose what they value most, either in terms of being mobile, being socially connected, or being comfortable in their homes or neighborhoods.

The capability approach helped us to gain in-depth understanding of the specific capabilities of older adults that contribute to independence as the functioning that they valued most. In so doing, we were able to go beyond core capabilities and the general functioning of wellbeing in later life. Through using the capability approach, our study uncovered a variety of subjective experiences, personal biographies and life projects in later life. 
This ties in to Entwistle \& Watt's (2013) recommendation, that a responsiveness to personal background is vital in organizing old-age care. What important capabilities are in later life, how agency is shaped, and what being independent means, differs between older adults (Gopinath, 2018). Developing an eye for such individual needs is important for policy makers, in order to create age-friendly environments that promote equity, with and for older adults.

\section{References}

Antczak, R. \& Zaidi, A. (2018). Well-Being of older Persons in Central and Eastern European countries. Research on Ageing and Social Policy, 6(1), 26-52. doi: 10.4471/rasp.2018.3109

Berg, P. van den, Sharmeen, F. \& Weijs-Perrée, M. (2017). On the subjective quality of social Interactions: Influence of neighborhood walkability, social cohesion and mobility choices. Transportation Research Part A: Policy and Practice, 106, 309-319. doi: 10.1016/j.tra.2017.09.021

Breheny, M. \& Stephens, C. (2009). 'I sort of pay back in my own little way': Managing independence and social connectedness through reciprocity. Ageing and Society, 29(8), 1295-1313. doi:10.1017/S0144686X09990134

Buffel, T., McGarry, P., Phillipson, C., Donder, L. den, Dury, S., Witte, N. de, Smetcoren, A. \& Verté, D. (2014). Developing age-friendly cities: Case studies from Brussels and Manchester and implications for policy and practice. Journal of Aging \& Social Policy, 26(1-2), 52-72. doi:10.1080/08959420.2014.855043

Custers, A.F.J., Westerhof, G.J., Kuin, Y., Gerritsen, D.L. \& RiksenWalraven, J.M. (2012). Relatedness, autonomy, and competence in the caring relationship: The perspective of nursing home residents. Journal of Aging Studies, 26(3), 319-326. doi:10.1016/j.jaging.2012.02.005

Davies, A. \& James, A. (2011). Geographies of ageing: social processes and the spatial unevenness of population ageing. Farnham: Ashgate. 
Douma, L., Steverink, N., Hutter, I. \& Meijering, L. (2017). Exploring subjective well-being in older age by using participant-generated word clouds. The Gerontologist, 57(2), 229-239. doi:10.1093/geront/gnv119

Dunér, A., \& Nordström, M. (2005). Intentions and strategies among elderly people: Coping in everyday life. Journal of Aging Studies, 19(4), 437451. doi:10.1016/j.jaging.2004.10.001

Entwistle, V.A. \& Watt, I.S. (2013). Treating patients as persons: A capabilities approach to support delivery of person-centred care. The American Journal of Bioethics, 13(8), 29-39.

doi:10.1080/15265161.2013.802060

Gilleard, C. \& Higgs, P. (2010). Aging without agency: Theorizing the fourth age. Ageing \& Mental Health, 14(2), 121-128. doi:

$10.1080 / 13607860903228762$

Gilroy, R. (2005). The role of housing space in determining freedom and flourishing in older people. Social Indicators Research, 74(1), 141158. doi: 10.1007/s11205-005-6520-5.

Gilroy, R. (2006). Taking a capabilities approach to evaluating supportive environments for older people. Applied Research in Quality of Life, 1(3-4), 343-356. doi:10.1007/s11482-007-9025-3

Gilroy, R. (2008). Places that support human flourishing: Lessons from later life. Planning Theory and Practice, 9(2), 145-163. doi:

10.1080/14649350802041548

Gopinath, M. (2018). Thinking about later life: insights from the capability approach. Ageing International, 43, 254-264. doi: 10.1007/s12126018-9323-0

Grewal, I., Lewis, J., Flynn, T., Brown, J., Bond, J. \& Coast, J. (2006). Developing attributes for a generic quality of life measure for older people: Preferences or capabilities? Social Science \& Medicine, 62(8), 1891-1901. doi: 10.1016/j.socscimed.2005.08.023 Hamilton-Baillie, B. (2008). Towards shared space. Urban Design International, 13(2), 130-138. doi: 10.1057/udi.2008.13 Hammarström, G. \& Torres, S. (2010). Being, feeling and acting: A qualitative study of Swedish home-help care recipients' 
understandings of dependence and independence. Journal of Aging Studies, 24(1), 75-87. doi:10.1016/j.jaging.2008.10.002

Hoven, B. van, Brouwer, A.E. \& Meijering, L. (2012). Introduction:

Geographies of ageing and well-being. European Spatial Research and Policy, 19(1), 9-15. doi: 10.2478/v10105-012-0002-y

Joffe, H. and Yardley, L. (2003). Content and thematic analysis. In Marks.

D.F. \& Yardley, L. (eds.). Research methods for clinical and health psychology (pp. 56-68). London: Sage.

Kendig, H. \& Phillipson, C. (2014). Building age-friendly communities:

New approaches to challenging health and social inequalities. In The British Academy (ed.), "If you could do one thing": Nine local actions to reduce health inequalities (pp. 102-111). London: the British Academy.

Kimberley, H., Gruhn, R. \& Huggins, S. (2012). Valuing capabilities in later life. the capability approach and the Brotherhood of St Laurence aged services. Brotherhood of St Laurence, Fitzroy. King, P. (2007). The concept of wellbeing and its application in a study of ageing in Aotearoa New Zealand. (Working Paper No. 8). Family Centre. Social Policy Research Unit, Wellington.

Kwaliteitsinstituut Nederlandse Gemeenten (KING) [Quality institute Dutch Municipalities] (2017). Gemeentelijke Monitor Sociaal Domein [Municipal Monitor of the Social Domain]. Available through: https://www.waarstaatjegemeente.nl. Kwaliteitsinstituut Nederlandse Gemeenten [Quality institute Dutch Municipalities], the Hague, accessed on July 31, 2018.

Lager, D., van Hoven, B. \& Huigen, P.P.P. (2015). Understanding older adults' social capital in place: Obstacles to and opportunities for social contacts in the neighborhood. Geoforum, 59(1), 87-97. doi: 10.1016/j.geoforum.2014.12.009

Leefbaarometer [Liveability Monitor] 2014. Leefbaarheidssituatie [Liveability]. Available through: http://www.leefbaarometer.nl. Ministry of the Interior and Kingdom Relations, the Hague, accessed on July 31, 2018. 
Lloyd-Sherlock, P. (2002). Nussbaum, capabilities and older people.

Journal of International Development, 14(8), 1163-1173.

doi:10.1002/jid.958

MacLeod, S., Musich, S., Hawkins, K., Alsgaard, K., \& Wicker, E. R. (2016). The impact of resilience among older adults. Geriatric Nursing, 37(4), 266-272. doi: 10.1016/j.gernurse.2016.02.014

Meer, M. van der, Droogleever Fortuijn, J. \& Thissen, F. (2008).

Vulnerability and environmental stress of older adults in deprived neighborhoods in the Netherlands. Tijdschrift voor Economische en Sociale Geografie, 99(1), 53-64. doi: 10.1111/j.14679663.2008.00439.x

Mitchell, L. \& Burton, E. (2006). Neighborhoods for life: Designing dementia friendly outdoor environments. Quality in Ageing and Older Adults, 7(1), 26-33. doi: 10.1108/14717794200600005

Nussbaum, M.C. (2003). Capabilities as fundamental entitlements: Sen and social justice. Feminist Economics, 9(2-3), 33-59. doi:

10.1080/1354570022000077926

Nussbaum, M.C. (2011). Creating capabilities, the human development approach. Harvard: Harvard University Press.

Ootegem, L. van \& Spillemaeckers, S. (2010). With a focus on well-being and capabilities. The Journal of Socio-Economics, 39(3), 384-390. doi:10.1016/j.socec.2009.11.005

Paulos, L. \& Fragoso, A. (2017). Reclaiming the community potential to improve the lives of older citizens. Research on Ageing and Social Policy, 5(1), 57-81. doi: 10.4471/rasp.2017.2450

Phillips, S. P., Auais, M., Belanger, E., Alvarado, B., \& Zunzunegui, M. (2016). Life-course social and economic circumstances, gender and resilience in older adults: The longitudinal International mobility in Ageing Study (IMIAS). Social Sciences \& Medicine - Population Health, 2, 708-717. doi:10.1016/j.ssmph.2016.09.007

Robeyns, I. (2005). The capability approach: A theoretical survey. Journal of Human Development, 6(1), 93-117. doi:10.1080/146498805200034266 
Robeyns, I. (2006). The capability approach in practice. The Journal of Political Philosophy, 14(3), 351-376. doi: 10.1111/j.1467-

9760.2006.00263.x

Robeyns, I. (2016a). The capability approach. In Zalta, E.N. (ed.), The Stanford Encyclopedia of Philosophy (Winter 2016 Edition).

Metaphysics Research Lab, Stanford University, Stanford. Available online at https://plato.stanford.edu [Accessed 31 July 2018].

Robeyns, I. (2016b). Capabilitarianism. Journal of Human Development and Capabilities, 17(3), 397-414. doi:

10.1080/19452829.2016.1145631

Rogers, S.H., Halstead, J.M., Gardner, K.H. \& Carlson, C.H. (2011). Applied Research in Quality of Life, 6(2), 201-213. doi:

10.1007/s11482-010-9132-4

Ryan, J., Wretstrand, A. \& Schmidt, S.M. (2015). Exploring public transport as an element of older persons' mobility: A capability approach perspective. Journal of Transport Geography, 48, 105-114. doi:10.1016/j.jtrangeo.2015.08.016

Schie, T. van, Froentjes, M., Berg, K. van der, \& Genk, J. van. (2004). Zorgen voor morgen. Een zoektocht naar nieuwe vormen van wonen, zorg en welzijn [Care in the future. In search of new forms of housing, care and well-being]. Groningen: Groningen Municipality.

Schwanen, T., Banister, D. \& Bowling, A. (2012). Independence and mobility in later life. Geoforum, 43(6), 1313-1322. doi:10.1016/j.geoforum.2012.04.001

Sen, A. (1993). Capability and well-being. In Nussbaum, M. and Sen, A. (eds), The quality of life. A study prepared for the World Institute for Development Economics Research (WIDER) of the United Nations University (pp.30-54). Oxford: Clarendon Press.

Sen, A. (1999). Development as freedom. Oxford: Oxford University Press.

Shura, R., Siders, R.A. \& Dannefer, D. (2010). Culture change in long-term care: Participatory action research and the role of the resident. The Gerontologist, 5l(2), 212-225. doi:10.1093/geront/gnq099

Smith, A. (2009). Ageing in urban neighbourhoods: Place attachment and social exclusion. Bristol: Policy Press. 
258 Meijering et al. - "I Think I'm Better at it Myself"

Stephens, C. (2016). From success to capability for healthy ageing: shifting the lens to include all older people. Critical Public Health. doi:

10.1080/09581596.2016.1192583

Stephens, C. \& Breheny, M. (2019). Healthy ageing. A capability approach to inclusive policy and practice. London: Routledge.

Thornberg, R. (2012). Informed grounded theory. Scandinavian Journal of Educational Research, 56(3), 243-259. doi:10.1080/00313831.2011.581686

Verkerk, M.A., Busschbach, J.J. \& Karssing, E.D. (2001). Health-related quality of life research and the capability approach of Amartya Sen. Quality of Life Research, 10(1), 49-55. doi: 10.1023/A:1016652515418

Volkert, J. \& Schneider, F. (2012). A literature survey of disaggregating general well-being: Empirical capability approach assessments of young and old generations in affluent countries. Sociology Study, 2(6), 397-416.

World Health Organization (WHO) (2007). Global age-friendly cities: A guide. Geneva: World Health Organization.

World Health Organization (WHO) (2015). Measuring the age-friendliness of cities. A guide to using core indicators. Geneva: World Health Organization.

Yeung, P. \& Breheny, M. (2016). Using the capability approach to understand the determinants of subjective well-being among community-dwelling older people in New Zealand. Age and Ageing, 45, 292-298. doi: 10.1093/ageing/afw002 
Louise Meijering. Assistant Professor. Faculty of Spatial Sciences, Population Research Center, Urban and Regional Studies Institute. University of Groningen.

Bettina van Hoven. Associate Professor. Faculty of Spatial Sciences, Department of Cultural Geography, Urban and Regional Studies Institute. University of Groningen.

Sepideh Yousefzadeh: Dr. Sepideh Yousefzadeh, University of Groningen.

Contact Address: University of Groningen, Faculty of Spatial Sciences, Population Research Centre, PO Box 800, 9700 AV Groningen, the Netherlands. 